\title{
A HISTORIC SUMMARY OF SCIENTIFIC KNOWLEDGE ON SEA LEVEL IN BRAZIL
}

\author{
Afrânio Rubens de Mesquita
}

\begin{abstract}
This is, perhaps, the first attempt to outline the history of the scientific knowledge of Sea Level and its variations in Brazil from its very beginning in 1500 to present days the beginning of the XXI century. Sea level measurements and tidal current reports from the local inhabitants are very much mixed up with an apparent unawareness of the phenomenon, from the first Portuguese reports on the new land. First long term measurements of sea level were taken in 1831, during the first Brazilian Kingdom, in the city of Rio de Janeiro, to determine local data for the mean sea level. It was only in the beginning of the XX century, after the proclamation of the Brazilian Republic in 1889 that the first publications reporting the scientific method to study sea level were published. Sea level values were then predicted by the National Observatory (ON) using a Kelvin predictor machine of sea level and were published the Tide Tables by the Directory of Hydrography and Navigation (DHN) of the Brazilian Navy. After the creation of the University of São Paulo (USP), 1934, the measurements and scientific method were solidly accepted for sea level studies. After an introduction with a general description of the sea level knowledge in the global context of the time, the sea level during colonial Brazil, the first sea level records, the measurements during the first Kingdom and Republic, the first scientific works by the researchers of the ON, by the DHN and from the USP are discussed.
\end{abstract}

Keywords: scientific history of sea level, Brazil from 1500 to 2000, Brazilian coast, National Observatory, Directory of Hydrography and Navigation, University of São Paulo.

RESUMO. Esta é, talvez, a primeira vez que se faz um esforço no sentido de descrever a História Científica do nível do mar e suas variações no Brasil, desde o seu começo, em abril de 1500, até os dias presentes, no início do século XXI. Há, aparentemente, falta de documentação entre os anos 1500 a 1700 , durante 0 período colonial. Documentos oficiais portugueses originários da Coroa, sobre o assunto, somente apareceram no começo do século XVIII. As primeiras medições do nível do mar foram tomadas em 1781, ainda um pouco antes do Primeiro Império, na cidade do Rio de Janeiro. Medições com o objetivo de se referir a um RN local para a transferência do nível médio do mar foram feitas durante 0 ano de 1831 no porto da cidade do Rio de Janeiro. Durante o Segundo Império sugiram os regulamentos a respeito da propriedade particular e da Coroa Portuguesa. Foi somente no começo do século XX, entretanto, depois da proclamação da República do Brasil em 1889, que ocorreram as primeiras publicações relevantes relacionadas ao método científico aplicado ao estudo do nível do mar. Valores do nível do mar eram então previstos pelo Observatório Nacional (ON), através de uma máquina de Kelvin e publicadas as Tábuas de previsão pela Diretoria de Hidrografia e Navegação (DHN) da Marinha do Brasil. Após a criação da Universidade de São Paulo (USP) em 1934, a medida e o método científico foram solidamente aceitos nos estudos do nível do mar. Nesta súmula, são historiados o conhecimento do nível do mar do Brasil colônia, os primeiros registros de nível do mar, as medições realizadas no primeiro Império e durante a República, os primeiros trabalhos científicos realizados no ON, na DHN e na USP.

Palavras-chave: história científica do nível do mar, Brasil de 1500 a 2000, costa brasileira, Observatório Nacional, Diretoria de Hidrografia e Navegação, Universidade de São Paulo.

Departamento de Oceanografia Física, Instituto Oceanográfico - USP, Praça do Oceanográfico, 191, 05508-900 Cidade Universitária, São Paulo, SP, Brazil. Phone: +55(11) 3091-6648 - E-mail: ardmesqu@usp.br 


\section{INTRODUCTION}

There are no records about the sea level knowledge on the Brazilian coast told by the locals, the populations of Tupi, Guarani and Tapuia ("Os Tupiniquins"), at the time Brazil was discovered. Unlike the ancient times, in Brazil, there were no Herodotus or Aristotle as in ancient Greece, neither Plinio as in the Roman Empire, or even scientist-writers like Cartwright (1999) to describe, puzzled, their theories about daily sea level variations observed on the Brazilian coast.

The arrival of the fleet of Pedro Alvares Cabral to the beaches of Ilha de Vera Cruz marked the meeting of two cultures, European and Tupiniquim, separated by thousand years of "evolution", which are since then struggling for their preservation. "Sailing is necessary while living is not" ("Navegar é preciso. Viver não é preciso") as the new-comers said then, who at the time initiated the science of cartography of the round Earth, the first steps to what 500 years later would be known as the globalization process.

Through navigation, knowledge of position, orientation and direction, they expanded their cultural influence "into unchartered waters" ("por mares nunca dantes navegados") as a way to increase their interests and businesses. The Dom Henrique Navigation School dates from 1418 and the first Global Navigation trip under the command of Vasco da Gama happened in 1499. In April 1500, Pedro Alvares Cabral journey, initially to India, extended "the influence of the nation of Camões" to the New World.

The confrontation of these cultures showed that they evolved at a different pace, and cultural elements of the Western civilization over 3,000 BC existed similarly in communities separated by tens of thousands of miles of unchartered seas, such as the unexpected hosts of the New World.

The understanding of the sky, the stars, the Earth, the movements of the sun and the moon, object of great concern were left to conjecture and to the "pajelâncias" as it was also left in the land of newly arrived visitors. There is no information whether the movement of the oceans in synchronization with the movement of the stars were described or interpreted by the local community and, even if there were, this information has probably been lost forever.

The Letter of Pero Vaz de Caminha does not mention either the navigation routes or the entries to the Brazilian ports at the time, known as "Roteiros", nor do they describe sea movement due to the tidal phenomenon or the establishment of landmarks indicative of sea level (Reference Levels, RLS).

From this view point, what happened in this clash of cultures, from 1500 to the present day, is the object of great interest and search in the local files and the files that survived the cataclysm of 1755 in the "Borealis" lands.

\section{BRAZIL COLONY AND THE FIRST KINGDOM}

The first record where the authorities show concern about the buildings being erected on the coast dates back to October 21 , 1710. The Royal Order of Portugal asks the governor of Rio de Janeiro to report on the buildings being built on the Navy and city beaches. Other Royal Orders followed until 1732 "asking the governor to inform about the convenience of measuring the distance between the sea and the buildings and to report it". Another one, "prohibited to build on the beaches or to advance even one foot into the sea by thus requiring the public good" and finally another "stating that the beaches and the sea are for public use and owners in the "testadas" cannot prevent the fishing nets to be launched" (SPU, 1999).

\section{The first records}

Sanches Dorta performed the first sea level measurements in the Guanabara Bay, next to the bar, between 1781 and 1782. About 120 years after Sir Robert Moray proposed the accurate measurements in England, in 1666; about 100 after the publication of the "Principia Mathematics" by Sir Isaac Newton in 1670 and also, about 80 years after Cassini's attempts to predict the tides based on the records of the relative sea level of the port of Brest in France (Cartwright, 1999).

\section{The Portuguese Crown in Brazil}

During the period when the Portuguese Crown was installed in Brazil, in 1808, a Decree of January 21, 1809 ordered "the sea lands of the Gamboa and Saco do Alferes beaches suitable for warehouses and wharfs, to be rented (decree that the land belonged to the Union). A notice from November 18, 1818 stated "15 fathoms of the sea water line and its coast are reserved for public use and that everything that touches and grows in the seawater belongs to the nation". A decree of September 13, 1820 gave jurisdiction to the Navy for the concession of any portion of the beach at all ports.

\section{The first kingdom}

During the first kingdom, after 1822, an Act of October 15, 1831 budgeted revenue and fixed expenses for the financial year 1832 1833, and a budget bill that dealt explicitly with the Navy sea land making it available to the Municipal Council, allowing the Province President to rent and set the rent of the Union sea land. 
The Union Sea Land was defined in the Navy Instruction number 348 of November 14, 1932. The first systematic measurements of tidal heights recorded are from 1831, and aimed to define, on the ground, the mean sea level of the port of Rio de Janeiro State. There is no news that these measurements have been performed for a period longer than a year.

\section{THE REPUBLIC AND THE SEA LEVEL}

In 1889, the Republic of the United States of Brazil was proclaimed and opened new horizons in the political landscape of the Ilha de Vera Cruz. However, there was nothing to indicate changes in the contributions, which since its "discovery" had happened towards increasing its cultural space. In 1905, the first attempt to organize a service for systematic measurements of relative sea level happened. This service was assigned to the Section of Hydrography of the Federal Inspection of Ports, Rivers and Canals, which maintained permanent stations for sea level measurements at all the mains ports of Brazil, from Chui to Oiapoque.

In Guanabara Bay, sea level measurements were performed in Santa Cruz, War Arsenal (former) Ilha das Enchadas, Itha do Bom Jesus, Ilha do Boqueirão, Ilha do Brocoió and Batalha, at the bottom of the bay and outside the Bay bar, in Imbuí. In the Laguna port, gauges to measure sea level were installed in Carniça, Cabeçudas, Estaleiro and Barra. The Barra tide station provided information about the ocean tides for its proximity to the open sea; the Estaleiro station provided tidal elements in the canal and Laguna port; Cabeçuda station provided tidal characteristics at the junction of the lagoons Santo Antônio dos Anjos and Imaruí and, finally, the Carniça station provided the information about secondary tidal waves that propagates towards Tubarão river.

\section{The characteristics of the measuring stations}

Tide gauge stations were completely sheltered from bad weather and, the facilities were built to meet the shape of the bay. Barra station was installed so as not to receive the influences of reflected waves. It was not advised to build stations at the bottom of the bays, "because the amplitudes of the tide are often greatly increased due to gradual depth decrease and there is also delaying of the phenomenon manifestation". The measurements were advised to be performed in Cabos, offshore islands and the open sea (pelagic measurements) in order to study the system back and tidal propagation in the oceans. The graduated scales for the measurement of relative sea level were called "tide meters" and the equipment, gauges were Seibt-Fuess floating type, of the Coast and Geodetic Survey, and pressure gauges were Favé type.

\section{The first scientific works}

The first works on the determination of harmonic tidal constants in the country, based on the relative sea level measurements, were performed by Alix Corrêa Lemos, in 1928 and Luiz Lecoq D'Oliveira, in 1912. These and works by Belfort Vieira (1928), in the first quarter of the century, began the process of assimilation of the scientific method to understand the tidal phenomenon in Brazilian lands, which also had arrived in Portugal. The Brazilian culture started then to assimilate the measuring procedures and the scientific method of description and analysis of the Old World, using them to explain and understand the phenomena related to relative sea level and local tidal currents.

\section{Measuring station network}

In the Southern Republic, there was progress in the construction and operation of a network of permanent stations to measure relative sea level, along now, the 8 thousand kilometers of the Brazilian coast. The first stations were built in the port of Rio de Janeiro city, in 1905, in Fortaleza (1910), Santos (1920), Pelotas (1930), Laguna (1906), São Francisco do Sul (1923), Florianópolis (1923), Itajaí (1922), Paranaguá (1928) and, Vitória (1917). While Salvador in 1918, Aracaju (1935), Recife (1935), Natal (1939) and Belém (1935), have records for the highest and lowest temperatures and atmospheric pressure at Portobras, the new port company of the new Republic, which was responsible for the installation and operation of the permanent observation stations of the relative sea level of the ports.

\section{THE SCIENTIFIC METHOD}

The assimilation of the scientific methods and results developed in Europe also met some progress in the works of Alix Corrêa Lemos on the harmonic method of tidal analysis and prediction of tides, both in 1912 and others on the dynamic theory of tides; on the Laplace investigations and also about the channel theory of Airy, published in 1928. Dated from about the same time, 1934, are the remarkable works by Belfort Vieira on the manifestation of tidal phenomena on the Brazilian coast and the causes of the tides; the deduction of the formula for the attraction potential of a star and its development in the study of harmonic analysis of 1936. The numerical prediction of tide levels at the port of Rio de Janeiro using a Kelvin machine (Fig. 1) 


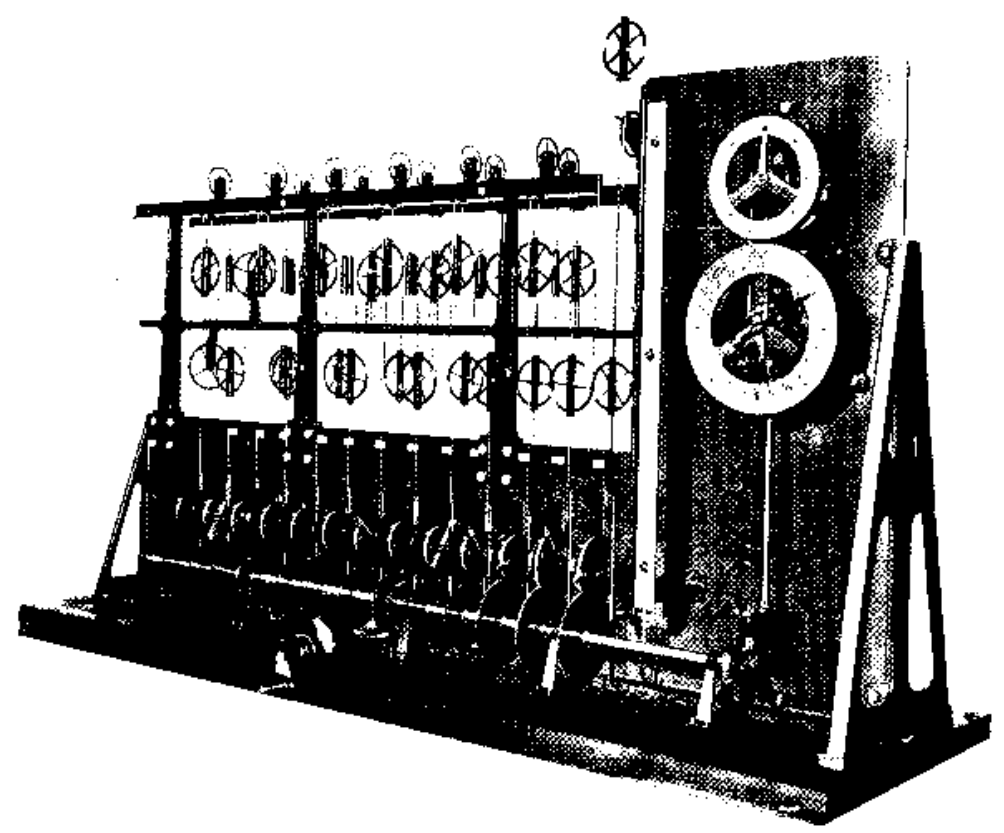

Figure 1 - Kelvin machine to predict tides. The system is driven by an electric motor which synchronously move the generating pulleys, whose radii represent the amplitude of the harmonic constants (M2, due to the Moon, S2, due to the Sun... etc.), and oscillate up and down with the frequency proportional to the ones known in Astronomy, and whose phases are incorporated in the initial position of each movement generating pulley. The generating pulleys are connected and drive the movable pulleys up and down. Through the movable and fixed pulleys passes a single wire that sums up the contribution of each generating pulley and the predicted tide (months or years) for a given port is recorded on paper. Photo by Alix Corrêa Lemos (1928).

started at the ON, in 1912, nearly 32 years after its invention in England.

\section{National Observatory and the Directorate of Hydrography and Navigation}

In Brazil, the Tide Tables traditionally provided by the ON (Fig. 1) currently a Research Institution of the Conselho Nacional de Pesquisas Científicas e Tecnológicas (CNPq), started being edited by the Directorate of Hydrography and Navigation (Diretoria de Hidrografia e Navegação), agency of the Ministry of the Navy of Brazil from 1964. The Tide Tables (Tábuas, 1989) for the main ports of the country and among them, the ports where permanent stations to measure sea level were kept, used the analysis method developed by Franco from 1938. When computers became available (1975), the Directorate started to calculate the harmonic constants M2, S2, M3 and others, using data from the permanent stations to measure sea level and the prediction of tidal heights using a processing unit IBM /370.

\section{The Universidade de São Paulo}

The Universidade de São Paulo, 1934, installed permanent stations to measure the relative sea level in the coastal cities of
Cananeia and Ubatuba, in São Paulo, in the 50s and still operates them through the Oceanographic Institute. The academic research on tides started as "Scientia Vinces", which spurred the creation of the State University, which has since greatly contributed to increase the quality of cultural heritage in Brazil. Through assimilation, the Oceanographic Institute of USP has developed methods of Fourier analysis of sea level by Franco \& Rock (1971).

The variations of relative sea level were analyzed by Mesquita \& Morettin in 1984 to determine the decadal and intradecacal scales of its variations, correspondence and causal relationship with the oceanographic/meteorological event El Niño in the same scales that occur in the Pacific, and its occurrence also in a causal relationship with the sunspots and rainfall in Fortaleza and San Francisco, USA.

The relative sea level data in 10-year series, obtained by the Coastal and Geodetic Survey of the United States in the 60s were analyzed by Mesquita et al. (1986), in Belém, Recife, Salvador and Imbituba, using the Fourier integral, continuing earlier work on sea level along the Brazilian coast (Belford Vieira, 1928). The characteristics of monthly, annual mean variability were described, and the correlations were estimated for this time scales, with the variables atmospheric rainfall, pressure, evaporation and solar radiation along the Brazilian coast. 


\section{THE LAST QUARTER OF THE XX CENTURY}

In the last quarter of the XX century, the development of the global communications by satellites, similarly to the invention of the Gutenberg press in the XVI century, resulted in the second explosive transmission of knowledge between different communities. The cultural heritage of the Roman Empire, including the New World, which was extended by the Lusitanian people and, now it includes also the cultural heritage of Africa and Asia, thus defining the cultural contours of what in the years to come would be understood, maybe as the Global Civilization that started in the $\mathrm{XV}$ century by the Lusitanian.

\section{CONCLUSIONS}

From 1500 to 2000, there was remarkable development of scientific knowledge in the European Community. Comparatively, the level of scientific knowledge in Brazil was greatly delayed which has been outlined throughout this summary. From 1500 to 1700 , this scientific knowledge did not exist in Brazil which, however, observed and absorbed the discovery of Sir Isaac Newton (1630) about the attraction between all masses in the planet and in the Universe, something that is not palpable. In 1781, about 150 years after Newton, the Portuguese astronomer Sanches Dorta performed the first measurements of tidal phenomena, which results from the attraction between the masses of the Earth, Moon and Sun; in reality, a phenomenon of Roto-gravity-inertial nature, taking into account all the physical processes that determine it. The daily and long-term variations of sea level were measured in the Guanabara Bay, Rio de Janeiro State. The first and second Kingdoms, however, did not acknowledge or absorbed the Fourier Integral (1822) that currently allows harmonic interpretation and prediction of phenomena resulting from harmonic and periodic variations of the distances and orbits of the masses that gravitate among themselves, Earth, Moon and Sun. The Second Kingdom regulated heavily the use of the beaches, but it was later, during the Republic, in the beginning of the XX century that systematic measurements of sea level were established in several ports along the coast. Since then, the scientific method to

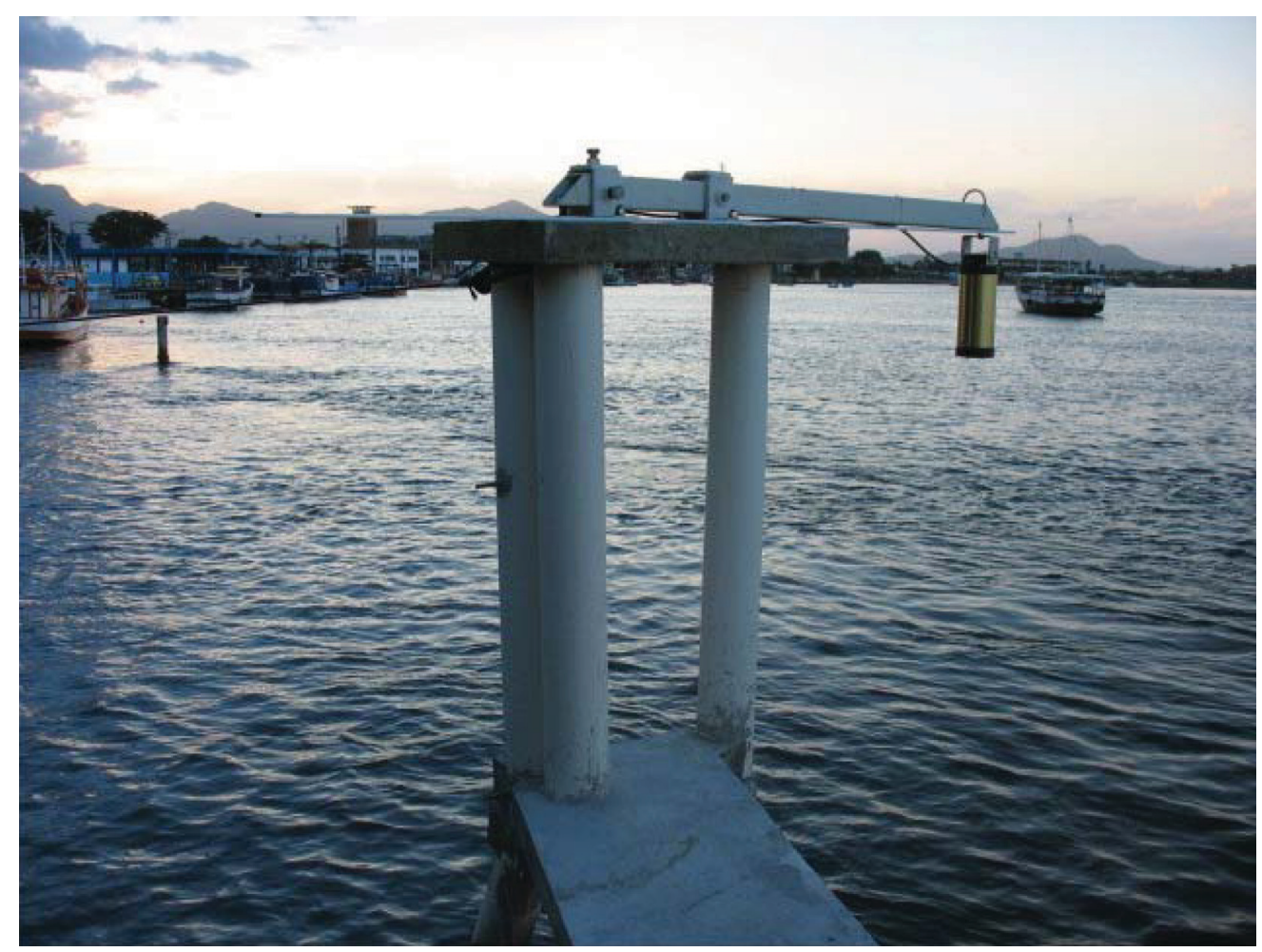

Figure 2 - Sea level gauge in operation at the José de Paiva Carvalho Reasearch Base of the Instituto Oceanográfico of the Universidade de São Paulo. Donated by Comissão Oceanográfica Internacional (COI/UNESCO). By emitting radar signals directed to the surface, the sea level variations are obtained by the time interval between the instants of transmission and reception of the reflected electromagnetic wave. Once calibrated, these differences produce sea level series at intervals shorter than two minutes. At the research bases of Cananeia and Ubatuba, the data are collected by Kalesto gauges, made in Germany that can be obtained at fttp://mar8.io.usp.br. 
analyze sea level was incorporated in the local culture, and several contributions were made between 1900 and 1938 by the researchers of the $\mathrm{ON}$ and the Diretoria de Hidrografia e Navegação (DHN). The scientific knowledge about the sea level developed after 1954 at the University of São Paulo, and more recently, in 1993, at the Instituto Brasileiro de Geografia e Estatística (IBGE), achieved levels of modernity where altimetric, gravimetric and geographical positioning satellites together with abyssal and radar (Fig. 2) and gravimetric local measurements provide high quality sea level data, real-time, enabling the development of ingenious uses of this important ocean variable.

\section{ACKNOWLEDGMENTS}

I am grateful for the profitable conversations with Eng. José Antônio dos Santos of the Instituto de Pesquisas Hidroviárias (INPH) and with Admiral Max Justo Guedes of the Serviço de Documentação Geral da Marinha do Brasil, in Rio de Janeiro. The Admiral Dr. Alberto dos Santos Franco allowed access to several interesting works of his property. At the request of its Director, Prof. Shoso Motoyama, I presented seminars on the subject to the colleagues of the Centro de História da Ciência of the Universidade de São Paulo, among them Prof. Milton Vargas, that were very useful to me.

\section{REFERENCES}

BELFORT VIEIRA JD. 1928. As Marés, Observação, estudo e Previsão no Brasil. Tese de Livre Docência. Universidade Federal do Rio de Janeiro, Brasil. Publicado em 1942. 169 pp.

CARTWRIGHT DE. 1999. Tides - A Scientific History. Cambridge University Press. Cambridge. UK. 292 pp.

FRANCO A DOS S \& ROCK NJ. 1971. The fast Fourier transform and its application to tidal oscillations. Bolm. Instituto Oceanográfico, Universidade de São Paulo. SP. (20): 1-33.

LEMOS AC. 1928. Marés e Problemas Correlativos. Observatório Nacional do Rio de Janeiro. RJ. 92 pp.

MESQUITA AR DE \& MORETTIN PA. 1984. Interannual variations of precipitation at Fortaleza, Ceará, Brazil. Tropical Ocean - Atmosphere News Letter N. 27, September, 1984

MESQUITA AR DE, FRANCO A DOS S \& HARARI J. 1986. On Mean Sea Level Along the Brazilian Coast. Part 1. Geophysical Journal of the Royal Astronomical Society of London, 87(1): 66-77.

SPU (Serviço do Patrimônio da União). 1999. Ministério da Fazenda da República do Brasil. Cronologia Básica da Legislação Patrimonial. $1 \mathrm{p}$.

TÁBUAS. 1989. Tábua de Marés para o Ano de 1989. Costa do Brasil e Portos Estrangeiros. Diretoria de Hidrografia e Navegação. Niterói. RJ.

\section{NOTES ABOUT THE AUTHOR}

Afrânio Rubens de Mesquita is a Physicist graduated from the Instituto de Física of the Universidade de São Paulo. Professor at the Instituto Oceanográfico of the Universidade de São Paulo and member of the Science History Center of the Universidade de São Paulo. 